\title{
Theoretical and Applied Aspects of Restriction of Corruption
}

\author{
Shemarov Valentin Aleksandrovich \\ Academy of law and management of the Federal Penal \\ Service of Russia \\ Ryazan, Russia \\ valentinerzn@mail.ru \\ Smirnov Sergey Nikolaevich \\ Academy of law and management of the Federal Penal \\ Service of Russia \\ Ryazan, Russia
}

\author{
Zaborovskaya Julia Mikhailovna \\ Chair of State and Legal Disciplines of Kuzbass Institute of \\ the FPS of Russia \\ Novokuznetsk, Russia \\ dum333@bk.ru \\ Pavlov Petr Aleksandrovich \\ Academy of law and management of the Federal Penal \\ Service of Russia \\ Ryazan, Russia
}

\author{
Saddarova Ksenia Olegovna \\ Academy of the Federal Penitentiary Service of Russia (Pskov branch) \\ Pskov, Russia
}

\begin{abstract}
- in this article we analyze theoretical and applied aspects of restriction of corruption offenses in modern Russian society and prove their social danger and systemic nature.
\end{abstract}

Keywords: corruption, fight against corruption, crime of corruption orientation, bribery, civil officer, civil society

\section{INTRODUCTION}

In recent years, domestic civil society is increasingly paying attention to the fact that in the field of distribution of social goods the existing legal regulation mechanism does not fully correspond to the public interests. In the development of the Russian state the accumulated problems and crisis phenomena have determined the priority directions for its improvement, because in essence it cannot be formed in isolation from economic, social, cultural, educational, spiritual and other factors that actually exist in the country.

In the field of limiting corruption the current legal policy of the state should be characterized by scientifically sound, systemically consistent activities of political, legal, organizational and managerial measures of public authorities which aims to eradicate this social disease. At the same time, it must be noted that at the present stage of the development of our state, all this activity focuses on the rule-making process, in which, trying to show wisdom, experience and knowledge in the management of the state and realizing their constitutional law, lawmakers of various levels and ranks come up with various legislative initiatives. And they naively believe that this is precisely the way that will help increase the effectiveness of the fight against corruption. As a result of this, new regulatory legal acts are constantly being adopted, amendments and additions are made to the existing ones, the adopted conflict ones are corrected by them, non-working ones are eliminated, compromised ones are canceled, etc. However, even a superficial analysis of these documents suggests that most of them are purely populist, and not practice-oriented. They are lack of specific, deeply thoughtout events that allow you to really fight this socially dangerous phenomenon. Such documents are lack of a large-scale scientifically based warning component. That is why their embodiment in real life has a very low efficiency. The detriment of this situation lies in the fact that the population of the country has formed a stable opinion that the adopted multilevel regulatory legal acts will hardly be implemented, but if they do, it will be very poor quality. As a result of this, there is a distortion of universal and legal values, legal nihilism is increasing, distrust of public authorities is growing, disappointment comes in the ideas of equality of citizens in front of the law, inevitability of punishment, justice, proportionality, etc.) [1].

It should be noted that the peculiarity of corruption is that it, arising in the field of administrative management, replaces public relations, which are legalized by various regulatory legal acts, which means that it creates an alternative to formal legal relations. Thus, any corruption in state and municipal authorities leads to abuse of power, harms the country's financial and economic activities. However, the biggest harm 
of corruption in government is that the country's population is deprived of a number of public benefits.

\section{METHODS}

Since the state's origin with its administrative staff officials at various levels have mercenary intent, which subsequently materializes into abuses which arise from the misuse of one's official position. In the modern sense, such official abuses are commonly called corruption. Corruption as a social phenomenon arises at a certain stage in the development of human society as an objective reality, because on the one hand it is based on the subjective imperfection of a person, and on the other hand, it is the objective imperfection of society. The origin of corruption was preceded by a long evolutionary process based on objective social inequality among members of society, in the process of which it becomes possible to derive benefits directly from one's social position. Consequently, corruption is the mercenary arbitrariness of entities endowed with power.

For many centuries, society has tried to combat this social ailment and achieved certain results. Nevertheless, in most countries of the modern world, corruption is at a fairly high level, and in some of them at a critical level, posing a threat to statehood itself. Unfortunately, the Russian Federation is one of such states, which causes particular concern among the population. The international anti-corruption movement, Transparency International, published the Corruption Perception Index (CPI) for year 2018. Russia took 138th place out of 180 and scored 28 points out of 100 . Over the past three years, Russia scored 29 points, and this year it lost one point and dropped to three places [2].

Most of the modern domestic criminologists note the fact that in recent years, officials of various government authority, as well as local authorities, have steadily participated in the corruption system, which is not only a breeding ground for organized crime, but in a number of regions it itself creates organized criminal groups in the government authority. According to statistics from the Ministry of Internal Affairs of the Russian Federation, only in January-October 2018, 69.3 thousand crimes of an economic and corruption orientation were identified, 22.7 thousand of which were committed on a large or especially large scale or caused major damage. Of the total number of crimes, 3.7 thousand were committed by a group of persons by prior conspiracy, and 4.9 thousand were committed by an organized group or by a criminal community. 15.2 thousand crimes of corruption were identified, including 7.7 thousand crimes against state power, the interests of public service and service of local government [3].

\section{RESULTS}

Given the high secrecy of corruption deals it should be noted that official statistics do not fully reflect the true extent of corruption in the country. In reality they are much higher. A number of authors state by commenting on the results of prosecutorial inspections that government authorities are amazed by corruption on a massive scale. Illegal actions of officials at various levels have embraced a wide range of relations regulated by legislation on state and municipal services, property, budget and procurement for state needs. The facts of unlawful participation of employees in commercial activities, ownership of shares and blocks of shares, occupation of paid positions in economic structures, failure to submit statutory declarations were constantly revealed [4].

According to the data of judicial investigative authority, officials of state authority and local self-government authority for the purpose of illegal enrichment commit offenses in the field of distribution of misuse of budget funds, tax concealment, distortion of financial statements, sale of land and etc. The most dangerous manifestations of corruption in this area are related clans, as well as when the criminal group includes officials of higher organizations, representatives of law enforcement agencies, members of criminal groups of various kinds.

\section{DISCUSSION}

Studying the problems of corruption, domestic criminologists distinguish the following signs: a) it is official; b) it is characterized by corporatism; c) it is an organization, that means, it has signs of stability and coordination of efforts; d) incompatibility of corruption and interests of the service; e) the size of the benefits and advantages provided to an official is not comparable with what the state can provide him for faithful and honest service [5]. These signs combine corruption in local government and organized crime at the local level. Organized crime is also partly official; it is characterized by corporatism, signs of organization; members of an organized criminal group do not complain about their salaries. The only difference from corruption is that they do not have to be in service of a state or municipal, and by necessity this group can and does commit any serious violent crimes, including contract killings, kidnappings and others. A feature of organized crime at various levels is the desire to monopolize power, which is supported by all kinds of criminal groups in every possible way.

Studying the main social causes of corruption, it should be noted that they are closely interrelated with such phenomena as the crisis and the imbalance in economic relations, high taxes, falling labor productivity, rising unemployment, budget deficits, etc. This criminal state of social and economic processes is promoted by legal nihilism not only of the population itself, but to a certain extent by the government, the deterioration of executive discipline and personnel work in local governments, an imperfect legal framework and certain limitations in law enforcement practice [6].

Unfortunately, most of Russian people are calm about the problem of corruption. In the public mind, there is a "selection" of priorities, when the main issues are problems of an everyday nature that they face daily (rising prices on food, medicine, goods and basic necessities, housing and communal services). On this background the problem of corruption and its manifestations in government is perceived as something distant and not related to them.

At the socio-psychological level, we can distinguish among the socio-moral causes of corruption: the traditional way for our country to solve problems through bribery, the 
of the state, in which control is initially regarded as a privilege of the highest authorities of state power. Corruption arising out of arbitrariness constantly expanded its presence in the state apparatus with its development. In the middle of 80 s of the last century, corruption struck a significant part of civil servants and, to a certain extent, was inherited by the current government apparatus [7].

However, before implementing the existing anti-corruption programs or starting to develop and adopt new regulatory legal acts in this area, it is necessary to develop a holistic national doctrine (concept) of the fight against corruption, which would combine all the main directions of this activity and become the basis of the legal policy of Russia. Otherwise, we will get again what we already have.

\section{REFERENCES}

[1] N.I. Polishrhuk, "Factors affecting the formation of the legal order in the country", Modern Law, 2018, no. 9, pp. 83-89.

[2] A. N. Poluboyarinova, "Criminological analysis of the determinants of crime against the interests of service in local authorities".

[3] Electronic resource. Available https://MVD.RU/reports/item/14696015.

Modern theoretical and applied jurisprudence proposes various measures to limit corruption. At the same time, all of them are subordinate to the desired, purposeful, systemic and rigid will of state power. Doctrinal science is rooted in the opinion that the desire for state power is a priori aimed at limiting corruption. At the same time, often the existing system of power cannot fully implement the mechanism of checks and balances. Unfortunately, the mechanism of the Russian state was originally built on the arbitrariness of state power and its full control over the society. The evolution of this mechanism quite logically led to the modern arrangement
[4] V. F. Nicevich, V. V. Moiseev, V. N. Prokuratov, "On the issue of combating corruption in Russia", Orel, 2015, pp. 84-88.

[5] Y. F. Kameneckiy, P. V. Kuncevich, and T. Y. Yubko, "Corruption: economic and criminological approach", Lawyer online. Electronic Law Journal [Electronic resource]. Available at: http://www.shkolny.com/2007/04/11/.

[6] A. N. Poluboyarinova, "Criminological analysis of the determinants of crime against the interests of service in local authorities".

[7] A. Kurakin, "Reform of the civil service of Russia should have an anticorruption focus", Russian Justice, 2002, no. 7, 24 p. 